\title{
A Consideration of Issues in the Government's Public Housing Projects in Post-War Iraq
}

\author{
Tara Abdulrazak $^{1}$ and Suguru Mori ${ }^{2}$ \\ 1. Graduate School of Engineering, Hokkaido University, Sapporo 060-8628, Japan \\ 2. Faculty of Engineering, Hokkaido University, Sapporo 060-8628, Japan
}

\begin{abstract}
Post-war Iraq is a mix of potential opportunities, promising intentions, and difficult challenges. After 2003, the government adopted a program to manage the housing crisis and satisfy housing needs. Through a fieldwork survey, we aimed to present this program by reviewing the government targets, main housing problems, governmental legislations, and construction process. We found that the government abandoned its centralized role in its National Housing Project as it opened the door of Iraqi housing market to foreign and local investors. We also found that, considering the enormous need for housing the occupancy rate of the governmental housing units are so low and construction is also generally slow. We deduced that the pricing model of the government's national housing project is far from our general notion of public housing for low-income post-war people. Moreover, it is necessary for the government to formulate a clearer strategic vision and to adopt more innovative approaches to address effectively and rapidly the trade-offs of the short and long terms objectives of the reconstruction process in post-war Iraq.
\end{abstract}

Key words: Post-war, public housing, reconstruction process, national housing project.

\section{Introduction}

Currently, Iraq is in a post-war situation, but the Iraqi situation bears two contradicting faces. On the one hand, there is the continuity of the conflict in the post-war era along with an unclear authoritative framework for what should be the basis for rebuilding society. The other face is the potential of Iraq such as its abundant wealth and human resources, in addition to its geographical location, which makes it a promising environment, that is, if the country's potential is accompanied by a well-managed reconstruction process. In general, the situation in post-war Iraq is characterized by continuous changes, floundering decision making process, and confusion in management and reconstruction planning. Currently, Iraq is facing problems of great magnitude: mass destructed areas in the cities, destruction of the basic infrastructure as roads, bridges, water supply, sewers,

Corresponding author: Tara Abdulrazak, $\mathrm{PhD}$ candidate, research fields: housing planning and design, developing housing design principles by investigating people social behavior and housing life style. E-mail: archtara@yahoo.com. and electrical grids, increasing number of homeless and displaced people, and population explosion in the cities due to immigrants and refugees.

Such background is accompanied by the will to reconstruct the country, especially rehabilitate its infrastructure in the housing sector. In connection with housing problems, the government adopted huge housing initiatives which are known as NHPs (national housing projects) to cover the post-war housing shortage, a shortage that has been accumulating since the pre-war era. By The NHPs, we refer to public housing solutions, which are proposed and implemented by the MOCH (ministry of construction and housing) either individually or in partnership with other ministries or other private investors. However, after eight years of reconstruction, we would like to shed some light on what happened in the housing sector during this period. In this paper, we aim to uncover the main problems, elucidate on the authoritative and the legislative background of the public housing projects in Iraq from 2003 to 2011, and to present the experiences of high-ranking officials and 
governmental architects of post-war Iraq on public housing.

\section{Fieldwork Survey}

To address our goals, we collected an extensive amount of data through field survey, interviews, and a collection of documents like legislation with regard to housing, the regulations and standards on housing design, housing manuals, and brochures. During our field survey in December 2011, we did comprehensive tours to the middle, the southern and the northern parts of Iraq. Our field work included visits to selected sites of completed housing projects from 2003 to 2011. In these visits, we took pictures and interviewed resident engineers and some of the inhabitants. To gather more concrete information, all the governmental offices responsible for the public housing projects in Iraq had been contacted; these offices are the MOCH (ministry of construction and housing), the SCB (state commission for building), and the SCH (state commission for housing). During the visits, the chief employers, the governmental architects, and the officers responsible for deciding on, the regulations, and the planning of housing in Iraq had been interviewed. Moreover, we visited a leading governmental construction company, AL MC (Mansur Company), a public company that carried out the construction of most of the post-war housing complexes, to collect detailed information like the project drawing sets and tables of work progress.

\section{The Status of Public Housing after the War}

At the moment, the public housing sector that is supposed to be handled by the government can be described as a complex mix between the government's objectives, housing problems, and what really is achieved by these housing projects. However the government targets in the housing sector can be summarized as follows: first and in accordance with the 2005 constitution of Iraqi, being ensured of a house is a right of every citizen [1]. To fulfill its constitutional commitments, the governments in Iraq, supported by the international community, initiated a large scale program to make it possible for each citizen to have what is called in the housing policy as a Decent Housing [2]. Second, from 2006, according to MOCH directives [3], the government is working on preparing plans to clear the slums, provide low-rent public housing units, and develop standards and rules of public housing in a way that respects the environmental and social principles of design. In 2010, the government in cooperation with the UN-HABITAT (United Nations Human Settlements Program) finalized the housing policy of Iraq [2]. Third, the government tried to build houses that are within the people's ability to purchase and pay. However, this ambitious plan is always subjected to the problems of housing production and to contradictions in the housing legislations.

\subsection{Housing Problems and Challenges}

The housing problems in Iraq could be divided into two parts: the first part concerns the housing needs (shortage) and the factors that hastened this shortage, and the second part concerns the problem of housing production.

\subsubsection{Housing Need}

When considering housing problems, we can immediately refer to the housing shortage. This shortage is an accumulated problem for three decades, that is, a problem that dates back before the war, it has been accumulating especially because of international sanctions on Iraq since 1991 [4]. The problem magnified after the war due to many reasons one of which is the natural growth of the population. As shown in (Table 1), Iraq has a population of 33 million in 2011. The average family size in Iraq is 6.9 [1]. In addition, major cities in Iraq suffer from the phenomenon of uncontrolled immigration due to the increased number of refugees and the displaced. This immigration in turn causes overcrowding and slum problems. 
Table 1 Estimations of the population, number of families and the Iraqi housing need from 2006 to 2015.

\begin{tabular}{lllc}
\hline Year & $\begin{array}{l}\text { Population } \\
\text { (people) }\end{array}$ & $\begin{array}{l}\text { Number of } \\
\text { families }\end{array}$ & $\begin{array}{l}\text { Housing } \\
\text { need(units) }\end{array}$ \\
\hline 2006 & $28,782,429$ & $3,737,978$ & 277,423 \\
2007 & $29,645,901$ & $3,850,117$ & 295,866 \\
2008 & $30,353,278$ & $3,965,621$ & 315,370 \\
2009 & $31,451,336$ & $4,074,589$ & 335,989 \\
2010 & $32,394,876$ & $4,207,127$ & 357,786 \\
2011 & $33,366,722$ & $4,333,341$ & 380,821 \\
2012 & $34,367,723$ & $4,463,341$ & 385,163 \\
2013 & $35,398,754$ & $4,597,241$ & 398,381 \\
2014 & $36,460,716$ & $4,735,158$ & 402,924 \\
2015 & $37,554,537$ & $4,877,213$ & 428,862 \\
\hline Total & & & $3,528,585$ \\
\hline
\end{tabular}

According to a UN-HABITAT report, more than two-thirds of Iraqis, or 71\%, are living in urban areas. In the urban areas, $13 \%$ of houses have more than 10 occupants, while $37 \%$ have three or more people per room. Moreover, 57\% of the urban population currently lives in slum-like conditions [5]. In addition, there is the continuous degradation of housing units due to ageing factor at a rate of $5 \%$ of the total houses in Iraq per year. In (Table 1), we see estimations of the housing need, originally prepared by MOCH. It should be noted that the calculation of housing need in (Table 1) was derived from the estimation of the population and the number of families, which were originally collected by the Ministry of Planning. The table refers, that the housing shortage in Iraq will reach 3,528,585 housing units by 2015, which, according to $\mathrm{MOCH}$ targets, should be covered within 10 years by producing 352,859 housing units per year starting from 2006.

\subsubsection{Problems Connected with Housing Production}

Problems of the housing sector in Iraq can be attributed to the lack of appropriate financial support, traditional way of building, problems of land use, and the absence of a strategic vision for post-war urban planning. Confusion in the management of financial resources and the outdated framework of housing construction are problems inherited from the pre-war era [4]. The failure in overcoming these problems in the post-war era casted a shadow to a large extent on the progress and the number of completed projects. On the other hand, the original city planning of Baghdad City dates back to the sixties of the last century [6]. The consecutive governments, both in pre-war and post-war, failed to adopt new city plans for a city that can accommodate, for instance, the following: industrial growth, agricultural growth, a booming city population, and post-war mega changes. Instead, the governments adopted unclear strategies in leasing lands. These strategies contributed to the lack, and to the high price, of appropriate land in urban centres for public housing projects [4]. Finally, the administration of the housing sector in Iraq ignored the important public debate among decision makers, professionals, and the academic community to discuss important questions in connection with post-war urban planning in Iraq, such as planning resources and strategies for slum development, dealing with city sprawling and expansion in a manner that addresses population needs, evaluating available housing resources, and stratifying the ethics of urban design like the necessity of reflecting the cultural and social characteristics of the Iraq community.

\subsection{The Main Governmental Legislations That Support the Housing Sector}

The governments in the post-war era considered a variety of legislative and administrative initiatives to organize the reconstruction process and to make the housing market in Iraq more attractive for the local and foreign investors. In an attempt to resolve the above mentioned housing problems, the governments adopted a vast deregulation process by lessening the centralized role of the government for the benefit of the provincial councils and by creating a variety of independent commissions. In this section, we briefly present and discuss the main legislative and administrative initiatives.

In an attempt to transform Iraq from the pre-war centralized economy to a new open market economic 
model, the cabinet PICM (presidency of the Iraqi Council of Ministers) adopted Investment Law No. 13 in 2006 [7]. The main objectives of this law are to open the door of Iraqi housing market to foreign and local investors, to promote the transfer of modern construction technologies and practices, to improve human resources, to enhance domestic growth by diversifying the base of Iraqi production and services, to expand market demands for jobs, and to improve the export-import trade balance in Iraq. According to the law, it is the duty of governments to facilitate the investment process by providing the following: the required privileges and guarantees to secure the continuation and the development of the investment process, exemptions from taxes, strict protection of investors' rights and properties, and the right of land ownership especially in housing projects. In addition, the government encouraged partnerships between the government and investment companies for state-owned enterprises. The outcomes of the above-mentioned investment law are the foundation of the NIC (national investment commission) and the PICs (provincial investment commissions). NIC is responsible for formulating the national policies for investment and for developing investment plans and regulations. NIC is specialized in federal strategic investment projects. PICs, on the other hand, do investment planning, they also oversee the construction of the investment housing projects, in coordination with NIC, on a regional level.

In an attempt towards decentralization, the government adopted Provincial Council law No. 13 and Region Law No. 21 in 2008 [8]. According to these laws, the PC (Provincial Council) and/or a regional authority are the highest legislative authority within the administrative boundaries of its own province (or region). In contrast to the Kurdistan Region which consisted of three provinces, the distribution of power and legislative authorities between the central government and the regions and provinces in the remaining parts of Iraq is vague, i.e., the distribution is rather inconsistent. This lack of clarity in power distribution and the absence of a hierarchical institutional structure are the reasons that explain the failure of local authorities in addressing the housing needs in their own regions [1]. Actually, the SCH in Baghdad still plays a central role in conducting housing projects in these regions, while the role of the local authorities are limited to granting lands and providing consultancy for these projects [9].

Finally, in an attempt to address the accumulated problems of housing shortage on a national level, in 2007, PICM founded the Committee of the NHP with the aim to develop solutions and proposals to resolve the ongoing housing crisis. Based on the recommendations and suggestions of this committee, the government adopted many housing rules and directives. Besides the Minister of $\mathrm{MOCH}$ and the general manager of NIC, the Committee consists of agents who represent the Ministry of Planning, the Ministry of Municipalities and Public Works, the Ministry of Finance, and the Mayoralty of Baghdad [9]. Some of the main activities of this committee are as follows.

In cooperation with the Iraqi housing fund, the NHP Committee began the distribution of lands and loans to the needy people under what is called the "urgent housing solutions". To increase the efficiency of this initiative, the Committee recommended the lessening of interest rates on these loans and the raising of the amount of loans. Based on an additional recommendation, PICM modified the administrative structure of "the Iraqi Housing Fund" according to law No.32 in 2011 by merging the Iraqi housing fund to $\mathrm{MOCH}$, the Fund is to be overseen by the Committee of Trustees, which is composed of agents from different ministries and is headed by the minister of MOCH [10]. Moreover, the budget of the Iraqi housing fund has been raised from approximately USD 275 million to USD 858 million. Currently, the Fund provides loans with low interest rates for Iraqis, with the exception of the Kurdistan Region. The Iraqi Housing Fund widened its scope to allow approved 
banks in Iraq to offer housing loans with low interest rates. Finally, it finances housing projects by Iraqi investment companies if the housing units are sold to citizens in installment.

In 2011, PICM approved the suggestion of the NHP Committee to decide on new rates of distribution (units per targeted class of residents) of the housing units in the completed projects in a manner that would secure benefits for war victims, martyrs, and the families of political prisoners. According to an SCH staff, the distribution rates are as follows: $30 \%$ for the displaced people, $30 \%$ for the unemployed people, $10 \%$ for the families of the martyrs of the Ministry of Defence, $10 \%$ for the families of the martyrs of the Ministry of the Interior, $10 \%$ for persons with disabilities and those with special needs, $5 \%$ for the widows, and $5 \%$ for the victims of terrorist attacks.

It can be noted from the above distribution rates that government employees will be excluded from the housing units built by the MOCH. The responsibility of satisfying the housing needs of government employees is shifted, under the new regulation, from $\mathrm{MOCH}$ to their own ministries. For that purpose, engineering bureaus have been established within every ministry [9]. These bureaus are in charge of constructing the housing projects for the governmental employee by investment. Finally, in 2010, the NHP Committee announced the project, House for Every Citizen. This project entailed the construction of economy houses in all the provinces of Iraq, except in the Kurdistan region. The estimated cost of the project is USD 2 billion. The government will allocate $2 \%$ of the state budget for this project every year.

\subsection{Progress in Housing Projects}

We shall discuss both the housing projects by the government after 2003 and the government-intended target to satisfy the housing need. Using $\mathrm{MOCH}$ documents (summarized in Table 2), we listed all the public housing projects that were supposed to be implemented under the supervision of the SCH. It is clear from (Table 2) that there are 38 planned housing projects from 2003 to 2011. From the 38, only seven housing projects were completed from 2003 to 2011 (Fig. 1), with an average completion rate of 4.7 years for every project. Moreover, (Table 2) reveals that there are only three projects for single detached houses, with two of them already completed. According to the managing director of SCB, the small proportion of the single detached houses is justified by space efficiency reasons, i.e., multi-story buildings can receive larger number of people. In an attempt to evaluate public housing productivity, we refer to the government plan to respond to the housing need. As mentioned in paragraph 3.1, to cover the housing shortage in Iraq, the government should build 352,859 houses per year from 2006 to 2015. To ensure fast productivity of the projects, the government allocated $85 \%$ of these projects to the private sector. The government intends to cover only $15 \%$ of the above-mentioned projects, which equals to 52,929 housing units per year, with the following allocation: $\mathrm{SCH}$ is supposed to cover $42 \%$, the other ministries $18 \%$, and $40 \%$ is supposed to be covered by the mixed economic sector [1]. That means $\mathrm{SCH}$ is supposed to cover 22,230 units in a year. However, MOCH can, according to the SCB general director [11], support the building of only five housing complexes with an average of 500-600 units for each complex within three years. Hence, the current target of housing production by MOCH is approximately 917 units per year; this is 21,313 units behind the supposed target. On the other hand, actual house production according to Table 2 is on average 321 units per year which is 21,909 units behind the supposed target and 596 units behind the current target. Clearly, there is incompatibility between actual production and the planned target. This incompatibility has been justified by reasons related partially to the housing problems mentioned in (3.1.2) and by the security situation of the post-war era. Most importantly, in contrast to the promised legislative and administrative initiatives, confusion and lack of clarity in the actual management 
Table 2 Public housing project for the post war Iraq.

\begin{tabular}{|c|c|c|c|c|}
\hline Year & Project (housing complexes) or Event & Number of units & Province & Completion period \\
\hline \multirow{3}{*}{2003} & Saba Abcar & 288 & Baghdad & From 2003 to 2008 \\
\hline & Haydaria & 432 & Karbala & From 2003 to 2010 \\
\hline & Panja Ali & 600 & Kirkuk & From 2003 to 2009 \\
\hline \multirow{2}{*}{2004} & Al Hadbaa & 504 & Ninawa & Under construction \\
\hline & Almudather & 516 & Messan & Under construction \\
\hline \multirow{6}{*}{2005} & Hay Al Sadder & 504 & Alkadisea & Under construction \\
\hline & Aljazeira & 624 & Karbala & Under construction \\
\hline & Umhalana & 504 & Wasit & Under construction \\
\hline & Sadder Al Yusefiea & 504 & Alkadisea & Under construction \\
\hline & Hay Alkudus & 504 & Alnajaf & Under construction \\
\hline & Hay Alhussaen & 504 & Basra & Under construction \\
\hline \multirow{2}{*}{2006} & \multicolumn{4}{|l|}{ Announcing the investment law } \\
\hline & \multicolumn{4}{|c|}{ Foundation of the national investment commission and the Provencal investment commissions } \\
\hline \multirow{8}{*}{2007} & Saida & 504 & Kirkuk & From 2007 to 2011 \\
\hline & Gas Wasswelem & 528 & Babel & From 2007 to 2010 \\
\hline & Hay Alsalaam & 588 & Alnajaf & Under construction \\
\hline & Kazaaa Alhay & 512 & Wasit & Under construction \\
\hline & Almudather2 & 504 & Messan & Under construction \\
\hline & Hay Al Jehad & 167 & Baghdad & From 2007 to 2011 \\
\hline & Alseadea & 49 & & From 2007 to 2011 \\
\hline & \multicolumn{4}{|c|}{ MOCH founded the committee of the national housing project } \\
\hline \multirow{7}{*}{2008} & Matarda & 512 & Salah Aldean & Under construction \\
\hline & Balad & 592 & Salah Aldean & Under construction \\
\hline & Gaswaswelem2 & 528 & Babel & Under construction \\
\hline & Alshuukh & 480 & Alkadisea & Under construction \\
\hline & Alshameia & 568 & Alanbar & Under construction \\
\hline & Al Ghalbea & 504 & Deala & Under construction \\
\hline & \multicolumn{4}{|c|}{ The government founded the provincial council's law } \\
\hline \multicolumn{5}{|c|}{\begin{tabular}{|l|l|l|}
2009 & \\
\end{tabular}} \\
\hline \multirow{8}{*}{2010} & Gatoon & 632 & Deala & Under construction \\
\hline & Jebeel Algurab & 632 & Alanbar & Under construction \\
\hline & Aljarbueea & 648 & Almuthanaa & Under construction \\
\hline & Sath Alarab & 640 & Basra & Under construction \\
\hline & Aldaghara & 656 & Alkadisea & Under construction \\
\hline & \multicolumn{4}{|l|}{ Housing policy was written } \\
\hline & \multicolumn{4}{|c|}{ the committee of national housing project put new rates for the distribution of the housing units } \\
\hline & \multicolumn{4}{|c|}{ The government announced the project of the economic houses } \\
\hline \multirow{15}{*}{2011} & Un Alasafer & 504 & Almuthanaa & Under construction \\
\hline & Arbajya & 728 & Ninawa & Under contract \\
\hline & Hay Al Kebla & 704 & Basra & Under contract \\
\hline & Alsuera & 604 & Wasit & Under contract \\
\hline & Aljazera2 & 624 & Karbala & Under contract \\
\hline & Samaraa1 & 800 & Salah aldean & Under contract \\
\hline & Makhmur & 107 & Makhmur & Under contact single housing unit \\
\hline & Heet & 432 & Alanbar & Proposed \\
\hline & Aana & 624 & Alanbar & Proposed \\
\hline & Suqseuukh & & Alkadisea & Proposed \\
\hline & Alrumetha & & Almuthna & Proposed \\
\hline & Alhamza & & Dewanea & Proposed \\
\hline & Alkaseem & & Babel & Proposed \\
\hline & \multicolumn{4}{|c|}{ MOCH decided that all the all the housing complexes to governmental employees to be built by their ministries } \\
\hline & MOCH announced the competition of & economic housing & design & \\
\hline
\end{tabular}


(Table 2 continued)

\begin{tabular}{|l|l|l|l|l|}
\hline Year & Project (housing complexes) or Event & Number of units & Province & Completion period \\
\hline \multirow{5}{*}{2012} & Gatoon & & Deala & Proposed \\
\cline { 2 - 5 } & Shatra & & Alkadisea & Proposed \\
\cline { 2 - 5 } & Hay Aleskaan & & Dewanea & Proposed \\
\cline { 2 - 5 } & Senjar & & Ninawa & Proposed \\
\cline { 2 - 5 } & Talafar & & Ninawa & Proposed \\
\cline { 2 - 5 } & Znhaleal & & Wasit & Proposed \\
\hline & Zerbatea & & Wasit & Proposed \\
\hline & Albetera & & Messan & Proposed \\
\hline
\end{tabular}

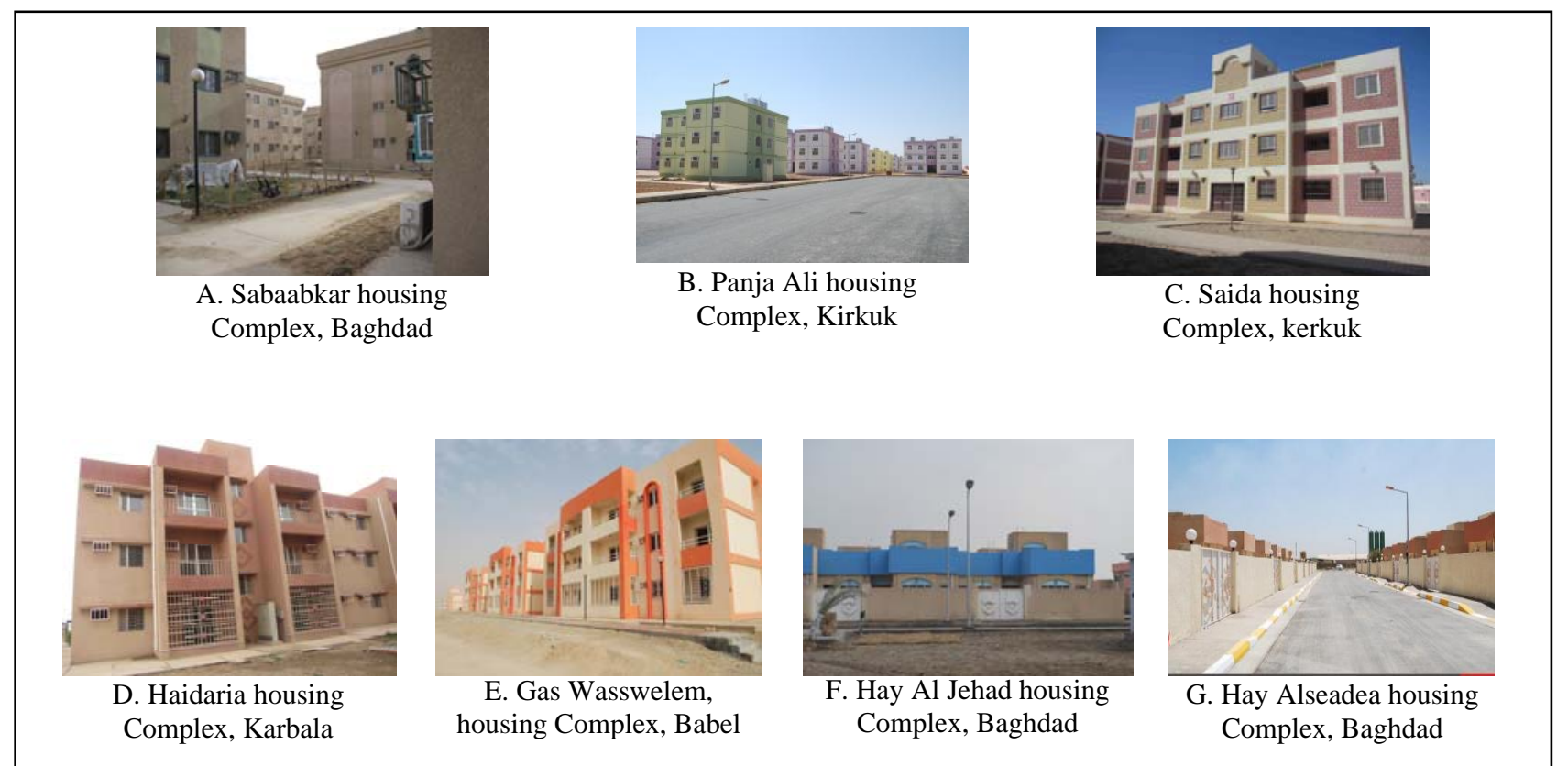

Fig. 1 Completed housing projects in postwar Iraq.

framework play an additional role in this low productivity rate.

\section{Discussions}

In this paragraph, we would like to evaluate the current reconstruction process from several perspectives. First, we would like to refer to the occupancy rates of the completed projects. Through survey, we found that, with exception of the Saba Abkar housing complex in Baghdad, the majority of the completed housing projects are empty. In (Figs. 2-3), we present the general architectural information of Saba Abkar and Haydaria complexes. Taking into consideration the crowdedness, the population explosion in the slums, and the severity of the housing demand in post-war Iraq, the low occupancy rate within the completed projects is a noticeable phenomenon. However, we believe that it is possible to understand this phenomenon by analyzing the pricing model for the housing units. It is noteworthy that the government is planning to sell all of the housing units at relatively high prices, compared to the income of an ordinary Iraqi family. This is especially true for investment projects that are to be implemented by ministries which target government employees, as discussed in section 3.2. In general, the employee is supposed to pay half of the unit price and the rest will be paid in installments by deducting half of the employee's salary per month. It is worth noting that a housing unit for a government employee costs more 
than USD 5,000, which is more than the average annual income for an Iraqi family, as the latter is estimated to be around USD 4,500 according to the Central Bank of Iraq. On the other hand, housing units that are covered by the national housing project and that targets the victims of post-war costs more than USD 6,800. The inhabitant is supposed to pay USD 1,300 and the remaining amount is paid by taking $50 \%$ from the inhabitant's salary. Taking into consideration that the majority of post-war victims are from the low income class, the pricing model can be described as expensive and inappropriate since it ignores the actual financial situation of the targeted families. It is possible to say that the above-mentioned pricing model is in sharp contrast to our common notion about public housing that usually targets low and middle income families, the suitable pricing model ought to be far below than $50 \%$ of the average monthly salary. It is clear that Iraqis, who have been living for many decades under a closed socially oriented market economy, are still reluctant to accept the sudden change towards an open capitalistic oriented market model that maximizes the benefits of the investment while undermining the social role of the government. At the same time, the governmental approach in addressing the problems and challenges of post war housing projects is characterized by slowness. It is clear from Section 3.3 that majority of the housing projects are far behind their completion schedule. Moreover, the governments consumed a long time in the enactment of the important legislations. For example, the economic housing project took eight years to be legislated. From other

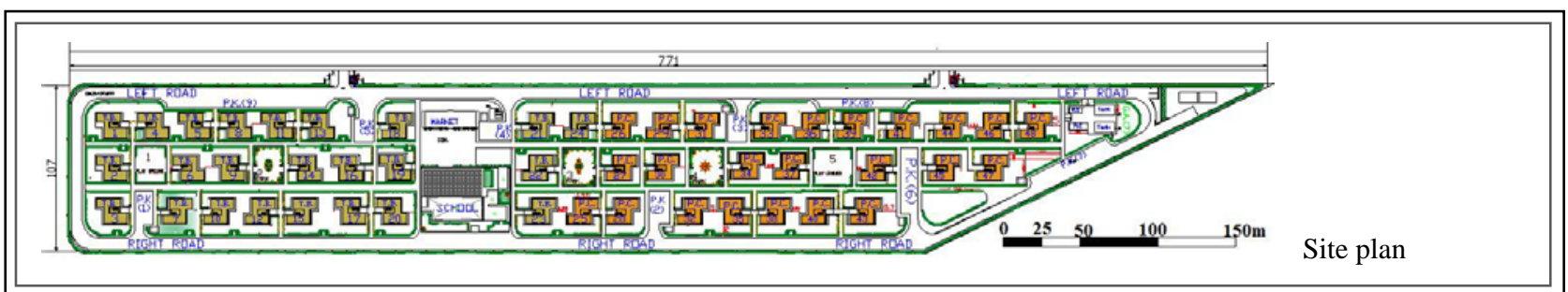

Site location: Saba Abkar housing complex allocated in the northern suburbs of Baghdad, on a land originally designed for agricultural use. The total complex area is 29 dunam (In Iraq, the dunam is 2,500 $\mathrm{m}^{2}$ ). The site contains 48 buildings. In order to achieve privacy between the buildings blocks, there are shift in the centers of the buildings locations to prevent direct line of view between the buildings windows. For that reason too, we don't see that usual grouping of blocks on a semi private open spaces that may enhance social contacts. The site contains five big green spaces but they are not distributed to be common to all the building. The complex also contains primary school, shops, security room, water tanks and sewerage treatment plan.

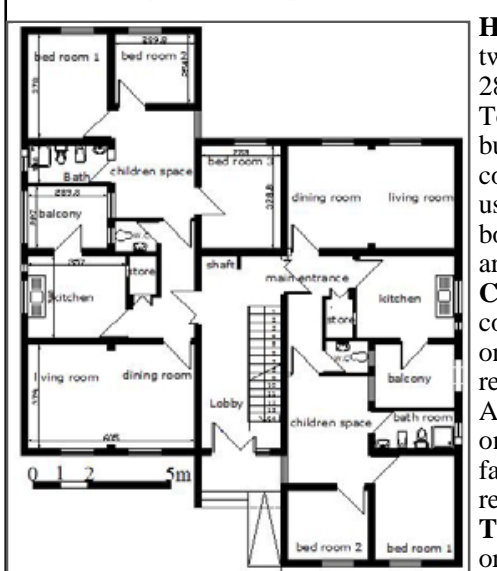

Housing buildings description: each of the 48 buildings is consisting of three stories. Every floor has wo flats, one with two bedrooms and the other with three bedrooms. The total number of flats is 288.144 of them has in area of $103 \mathrm{~m}^{2}$ per flat, while the reminder of them has an area of $115 \mathrm{~m}^{2}$ per flat. Total housing space for the 48 buildings is $35.232 \mathrm{~m}^{2}$. The external treatment of the façades divides the building blocks into two groups, we later found that such division was due to the difference in the construction systems. The first group used the cement rendering and stonework, while the other group used the emulation paint with different colour to give a sense of variety to the repetition of the building boxes. The façades also characterized by a rhythm of Arabic arches repeated in the balconies walls or as architectural treatment for the solid walls or as definition to the entrances by changing the arch size.

Construction of the housing buildings: The complex was constructed according to two different construction systems. 24 of the housing buildings were constructed by precast concrete panels depending on imported technique, Tracoba from France, which is now regarded to be globally obsolete. The reminders were built by skeleton system of load bearing concrete columns and beams with brick infill. According to the residents most of the precast buildings suffer from deep construction problems like omitting of the parapets, problems in the panels joints and the waterproofing. Precast concrete system is faster than the traditional way of building, however the schedules of the project working progress revealed that, in contrast to our assumption, it took longer than the traditional way of building.

The housing unit: Every flat contains DL (dinning-living) space, bath and toilet, kitchen, store and two or three bed rooms. Flat spaces originally designed to be constructed by the precast concrete. So each space tends to be small. Despite the small size of the spaces in regard to the Iraqi family requirement, still space arrangement respects the gradation of space utilities from the public to the more private in connection with the social way of living. The complex is fully occupied. Housing capacity is supposed to be five to six persons per flat. However actual status exceeds sometimes to10 persons per flat.

Fig. 2 Sababkar housing in Baghdad [12]. 


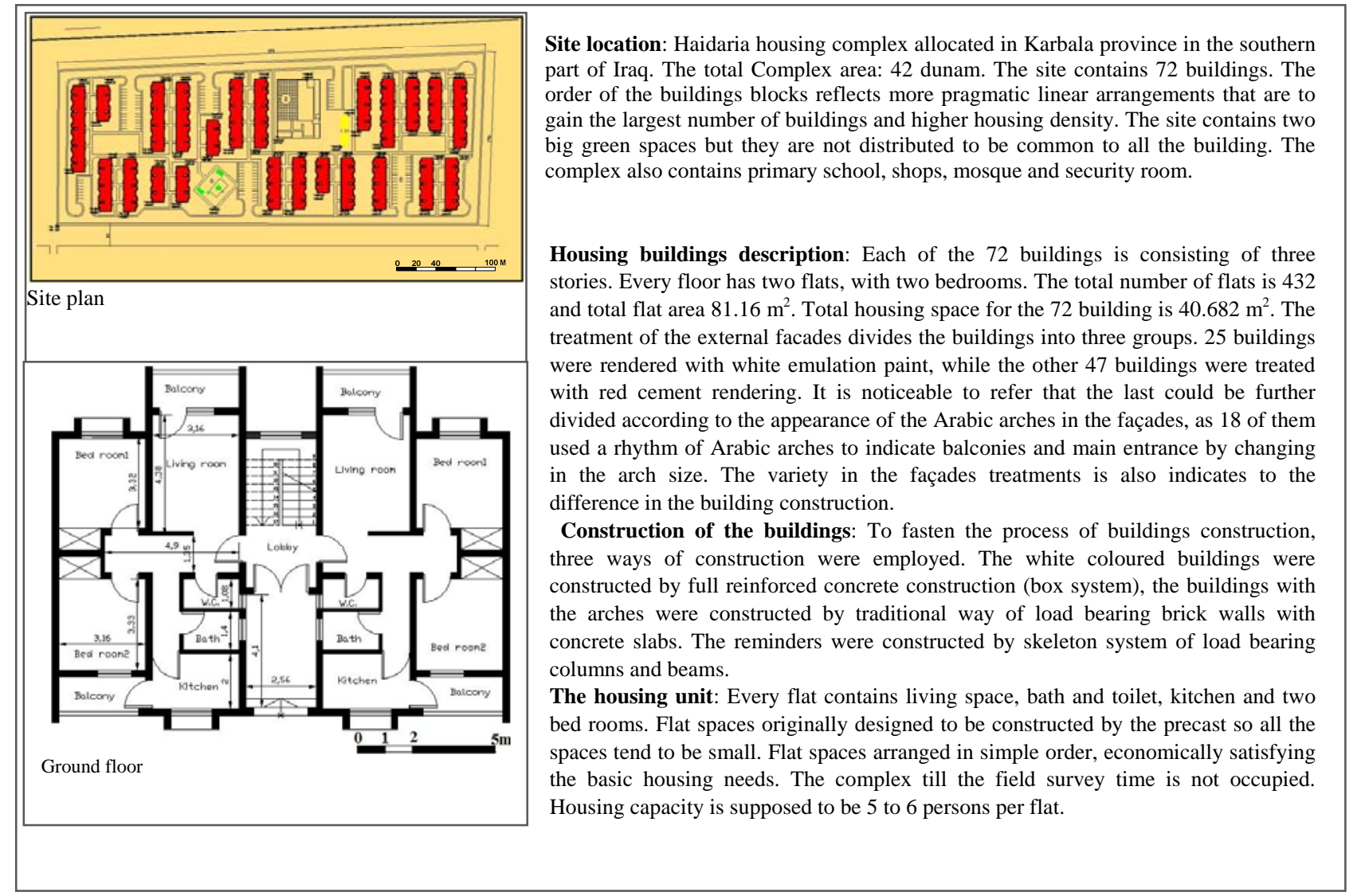

Fig. 3 Hajdaria housing, kerbala [12].

side, in considering the above mentioned governmental legislations, there is obvious omission to the urgent housing solutions. For example planning for post war housing in Iraq neglected the role of the temporary or emergency housing, which is expected and supposed to have become the focus of post war disaster relief plan, as it is the usual for a country undergoing post war situations. As a result the victims of the post war era are still, after nine years of the war, inhabiting the slums and the arbitrary housing.

\section{Conclusions and Future Work}

Iraq is in a post-war situation. In an attempt to recover from the damages of war, the governments in Iraq initiated a huge reconstruction process with ambitious goals, including the rehabilitation of the housing sector. In this paper, we shed light on Iraq's post-war reconstruction experience by utilizing the outcomes of a fieldwork survey. We discussed the current status and the main problems and challenges that face the reconstruction of the housing sector. We presented the main legislative and administrative efforts that support the ongoing reconstruction process. Then, we discussed the progress of the construction process and the relation between governmental housing management and the real housing situation.

In the conclusions, we aim to discuss the suitability of the government's post-war housing program. Two points attracted our attention: the tardiness of the building completion process and the tardiness in the enactment of important decisions (the economic housing project took eight years to be legislated). The tardiness could be traced back to the (problem-solution) method used by the government and this method's relation to the priorities of the housing problem. From our point of view, both homelessness and the lack of planning in construction management (from city planning to flats design) spring from the main 
problems of the post-war housing reconstruction program. However the methods to address these two issues are completely different.

We want to declare that the post-war situations require two things: (1) quick solutions to urgent problems such as homelessness, and (2) intensive researches on post-war characteristics and people's way of living (for a well-designed permanent housing and well-designed city that may take years to be completed). Due to this complicated case, we suggest a two-pronged method in solving the problem. First, it is necessary to use straightforward practical thinking to address the immediate needs of the homeless for temporary shelters instead of the spontaneous slums that people built for themselves. Second, it is also necessary to develop and use systematic thinking (for the basic design of the city and for the space arrangement of the housing unit) where the problems supposed to be more structured and the new design trends supposed to adapt itself to the new characteristics of the post war Iraq (Fig. 4). For the latter method, it is useful to mention the development cycle of Lonberg and Holm [13] for more complex thinking (i.e., thinking that deals with the indirect relation between need and tool). The cycle consists of six steps: research, design, production, distribution,

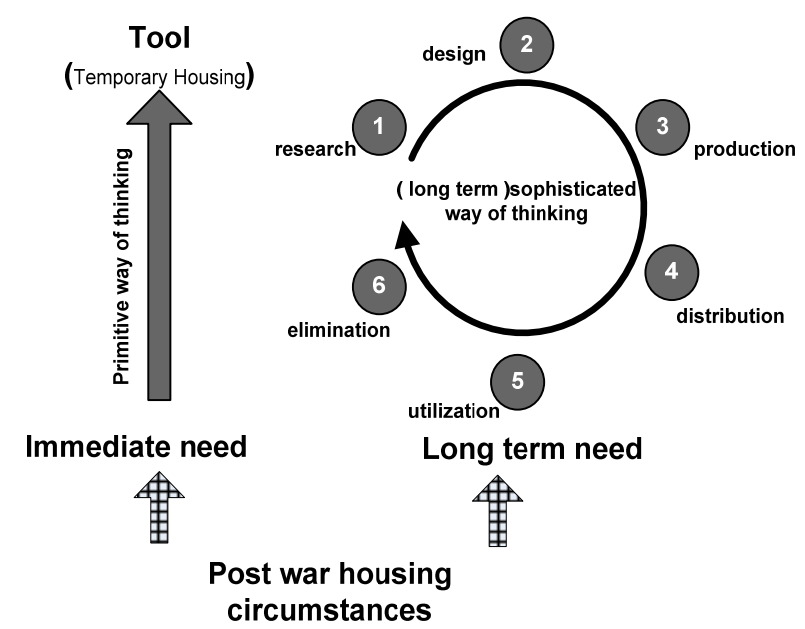

Fig. 4 Vision of the two-pronged problem solving method according to the immediate and long term housing need in Iraq, (The long term development circle is driven from Lonberg and Holm development circle [13]). utilization, and elimination. This cycle reveals the important role of the architects' and planners' research on permanent housing that is built on social and environmental principles. Our suggestions were strengthened when we found out about the government's aim and the target of MOCH (i.e., decent housing for the Iraqis). We know that satisfying this goal of decent housing, by its entire means, may take a long time.

Despite our insistence for a temporary housing, which in itself is now late for nine years considering that such housing is meant for people who cannot wait for years for a shelter, this cannot be regarded as a solution.

Post-war maintenance cannot be completed without reference to a master plan (a long term commitment to a principle). Lacking articulated principles of development can do as much harm as the war did in its destruction of buildings and human society.

For the reconstruction process to achieve its goals, it is necessary for the government to adjust the pricing model of the completed projects and to adopt a more innovative approach to effectively and rapidly address the trade-off between the short term and the long term objectives of the reconstruction process.

In the future, we shall complete the second part of this review. Specifically, we shall discuss the design of the housing units as well as the main motivations, policies, and regulations that affect the final product.

\section{References}

[1] I. Al Shouk, Housing a reality in Iraq and the future vision of its advancement, in: The Symposium of Iraqi Economy Development Centre, Baghdad, Iraq, 2009. (in Arabic)

[2] Ministry of Construction and Housing and the UN-HABITAT (United Nations Human Settlements Program), Iraq National Housing Policy, Baghdad, Iraq, 2010.

[3] Interview with employees in the planning affairs of the Ministry of Housing and Construction, Dec. 7, 2011.

[4] PADCO, Community Development Group, Iraqi Central Office of Statistics and Information Technology, Iraq housing market study, main report, Ministry of 
Construction \& Housing, UNHABITAT and the World Bank (IFC), Iraq, 2006.

[5] IAU (Inter-agency information and analysis unit) and the UN-HABITAT (United Nations Human Settlements Program), Fact Sheet: Housing and Shelter in Iraq, world habitat day, Oct. 2009.

[6] Ministry of Construction and Housing, The State Commission of Housing, Urban Housing Standard Manual, Baghdad, Iraq, 2001.

[7] Iraqi investment law No. 13 of 2006, available online at: http://www.moch.gov.iq/istthmar\%20law.htm. (in Arabic)

[8] Iraqi Provincial Law No. 21 of 2008, the Iraqi council of representative, available online at: http://parliament.iq/english/index.php?newlang=english. (in Arabic)

[9] Interview with the Director of the SCH Legal Affairs, Dec. 9, 2011.

[10] Iraqi Housing Fund Law No. (32) of 2011, Iraqi Local Governance Law library, available online at: http://www.iraq-lg-law.org/ar (accessed Nov. 10, 2012). (in Arabic)

[11] Interview with the chief Director of SCB, Dec. 12, 2011.

[12] Brochure of Architectural Housing designs from 2003-2011, Ministry of Housing and Construction, Iraq, 2011.

[13] S. Chermayeff and C. Alexander, Community and Privacy, Toward a New Architecture of Humanism, Anchor Books, USA, 1965. 